\title{
Molecular characterisation of an Australian isolate of Bonamia exitiosa
}

\author{
Serge Corbeil ${ }^{1, *}$, Isabelle Arzul ${ }^{2}$, Maeva Robert ${ }^{2}$, Franck C. J. Berthe ${ }^{3}$, \\ Nathalie Besnard-Cochennec ${ }^{4}$, Mark St. J. Crane ${ }^{1}$ \\ ${ }^{1}$ AAHL Fish Diseases Laboratory, Australian Animal Health Laboratory, CSIRO Livestock Industries, Private Bag 24, \\ Geelong, Victoria 3220, Australia \\ ${ }^{2}$ IFREMER Laboratoire Génétique et Pathologie, Ronce-les-bains BP 133, 17390 La Tremblade, France \\ ${ }^{3}$ Department of Pathology \& Microbiology, Atlantic Veterinary College, University of Prince Edward Island, Canada \\ ${ }^{4}$ IFREMER, BP7004, Taravao, Tahiti, French Polynesia
}

\begin{abstract}
An Australian (New South Wales) isolate of Bonamia was characterised at the molecular level by sequencing the 18S-ITS-1 region of the small subunit rRNA operon obtained from flat oysters Ostrea angasi shown to be infected by histological examination. Sequence data alignment with homologous genes from 2 other isolates of Bonamia (New Zealand and France) revealed high levels of nucleotide identity with both isolates. However, the Australian Bonamia is shown to be more closely related to the New Zealand isolate, suggesting the existence of an oceanic subgroup of Bonamia.
\end{abstract}

KEY WORDS: Bonamia species · Ostrea angasi $\cdot$ Flat oyster $\cdot$ Small subunit rRNA operon

\section{INTRODUCTION}

Translocation of live molluscs is generally recognised as a major underlying cause of the spread of molluscan pathogens and diseases (Berthe et al. 1999). Bonamiosis, an infectious disease caused by haplosporidian parasites of the genus Bonamia, is one such example; in the northern hemisphere, the disease caused by $B$. ostreae is believed to have been introduced into Europe via European flat oysters Ostrea edulis imported from California, USA (Cigarría \& Elston 1997, Grizel 1997). These studies were based on available documentation of trade and transfer of oyster spat between California and Europe. Subsequent molecular characterisation and sequencing of the small subunit (ssu) rRNA operon of Bonamia species confirmed the broad northern hemisphere distribution of B. ostreae (Carnegie et al. 2000, Cochennec et al. 2000). Conversely, since its redesignation as B. exitiosa (Hine et al. 2001, Berthe \& Hine 2003), the exact distribution and geographical range of this antipodean Bonamia is unclear (Hine 1996, Campalans et al. 2000, Burreson et al. 2004, Kroeck \& Montes 2005), but this information is of central importance to better address management of disease caused by this serious pathogen (OIE 2003). Sequence comparison of the 18S gene and Internal Transcribed Spacer 1 (ITS-1) region of the ssu rRNA operon has helped clarify the taxonomic position of these intra-haemocytic parasites and has led to the development of diagnostic methods capable of detecting and distinguishing different isolates - resources essential for the development of health surveillance, disease monitoring and oyster stock translocation programmes (Carnegie \& Cochennec 2004).

A parasite belonging to the genus Bonamia was first reported in Australian flat oysters Ostrea angasi from Port Phillip Bay (Victoria), Georges Bay (Tasmania) and Albany (Western Australia) in the early 1990s (Hine \& Jones 1994), with no further certitude regarding species affiliation. Specification of Bonamia sp. is important in order to include or exclude $B$. exitiosa, as well as exclude Mikrocytos roughleyi, which was redescribed recently as a Bonamia bona fide (Cochen- 
nec-Laureau et al. 2003). A recent epidemiological study of bonamiosis carried out in southern New South Wales (NSW), Australia (Heasman et al. 2004), has allowed us to identify and characterise a Bonamia isolate at the molecular level and to establish its relatedness to other described Bonamia species.

\section{MATERIALS AND METHODS}

Australian isolate of Bonamia sp. Ethanol (70\%)fixed, Bonamia-infected flat oysters Ostrea angasi, collected from the Merimbula estuary in NSW (during 2003), were provided by Dr. Symon Dworjanyn (NSW Fisheries, Port Stephens) (Heasman et al. 2004). A total of 200 oysters, ranging from 80 to $120 \mathrm{~mm}$ in diameter, were sampled from the site, and histological sections were examined by light microscopy. Of several samples confirmed positive, 3 were used for sequencing analysis.

DNA extraction. Oyster tissues (mantle and gills) were rinsed in phosphate-buffered saline $(\mathrm{PBS} \mathrm{pH}$ 7.4), and then DNA was extracted using a QiaAmp DNA minikit (Qiagen) according to the manufacturer's instructions. DNA was eluted and resuspended in a final volume of $100 \mu \mathrm{l}$ sterile deionised water.

Table 1. Primer sequences used for amplifying and sequencing Bonamia rDNA 18S-ITS-1 gene sequences. The positions of the primer sequences correspond to the Australian Bonamia sp. 18S-ITS-1 rRNA sequence deposited in GenBank (Accession Number DQ312295)

\begin{tabular}{|lll|}
\hline Name & \multicolumn{1}{c|}{ Sequence 5'-3' } & Primers position \\
\hline 18S For-A & TGCATGTCCAAGTATAAACACG & $53-74$ \\
18S Rev-A & AACGCGATCCGACAAAATA & $250-233$ \\
18S For-B & TCGCGGGAGTGCATATTAG & $186-204$ \\
18S Rev-B & GGATGTGGTAGCCGTTCTC & $389-370$ \\
18S For-C & TGAGAAACGGCTACCACATC & $369-388$ \\
18S Rev-C & GGGGGCAGATATCCAACTAC & $617-598$ \\
18S For-D & CGACTAAGCATTGGGCTACC & $1026-1045$ \\
18S Rev-D & GTGGGGTCTCGTCCGTTAT & $1319-1301$ \\
18S For-E & CGAGACCCCACCCATCTAAC & $1309-1328$ \\
18S Rev-E & CAAAGGGCAGGGACGTAATC & $1640-1621$ \\
18S For-F & GCTGTTAAAACGCTCGTAGTTG & $583-604$ \\
18S Rev-F & ATCATTACTCCAGCTCAAAACCA & $856-830$ \\
18S For-G & CGGGCCAGAGGTAAAATTC & $884-902$ \\
18S Rev-G & CCCCCTGAGTCCGAAAAC & $1094-1077$ \\
18S For-J & GTGCATGGCCGTTCTTAGTC & $1253-1272$ \\
18S Rev-J & TTGCCCCAATCTTCCATCT & $1436-1418$ \\
18S For-M & GAATGCGGGTTCGATTC & $339-355$ \\
18S Rev-M & TTGGGTAATTTGCGCACC & $420-403$ \\
18S For-N & CTTCGGCGCCGCCAC & $797-811$ \\
18S Rev-N & GCTTTCGCATAAGTTAG & $935-919$ \\
ITS For-7 & ATTACGTCCCTGCCCTTTGT & $1622-1641$ \\
ITS Rev-7 & ACGAGGTTCGCGGTTTTAT & $1859-1840$ \\
ITS For-8 & CGTAACAAGGTTTCGTAGGT & $1757-1777$ \\
ITS Rev-8 & TGCTTTTTGCGTTTGTGTAGT & $1911-1891$ \\
\hline & & \\
\hline
\end{tabular}

PCR amplification of the rRNA 18S gene and ITS-1 region. Taq DNA polymerase (Promega) was used for PCR assays. In all PCR assays, the primers (Table 1) were used at a final concentration of $1 \mu \mathrm{M}$. Aliquots $(2 \mu \mathrm{l})$ of DNA samples were added to $23 \mu \mathrm{l}$ of reaction mixture for amplification. Thermocycling conditions for the $18 \mathrm{~S}$ gene PCR were: $95^{\circ} \mathrm{C}$ for 2 min (1 cycle), followed by $94^{\circ} \mathrm{C}$ for $30 \mathrm{~s}, 55^{\circ} \mathrm{C}$ for $45 \mathrm{~s}$ and $72^{\circ} \mathrm{C}$ for $45 \mathrm{~s}$ ( 40 cycles), followed by $72^{\circ} \mathrm{C}$ for $5 \mathrm{~min}$ ( 1 cycle). PCR cycling conditions for the ITS region were: $95^{\circ} \mathrm{C}$ for $2 \mathrm{~min}(1 \mathrm{cycle}), 94^{\circ} \mathrm{C}$ for $30 \mathrm{~s}, 50^{\circ} \mathrm{C}$ for $45 \mathrm{~s}$ and $72^{\circ} \mathrm{C}$ for $45 \mathrm{~s}$ ( 40 cycles), followed by $72^{\circ} \mathrm{C}$ for $5 \mathrm{~min}$ ( 1 cycle). The resulting amplicons were resolved by electrophoresis in $2 \%$ agarose gels in $1 \times$ TAE $(0.004 \mathrm{M}$ tris-acetate, $0.001 \mathrm{M}$ EDTA) buffer. Gels were stained with ethidium bromide $\left(0.5 \mu \mathrm{g} \mathrm{ml}^{-1}\right)$. Amplicons were then extracted using a gel extraction kit (Qiagen) before sequencing.

Sequence determination and comparison. The $18 \mathrm{~S}$ rRNA gene and the ITS region (GenBank Accession Number DQ312295) of the Australian Bonamia isolate were determined by direct sequencing of the PCR product using an ABI PRISM Ready Reaction Big dye Termination Cycle Sequencing Kit (Perkin-Elmer) and an ABI PRISM Model 377XL DNA sequencer (Sequencing Analysis 3.4.1 software Version 2.6) (Perkin-Elmer). All sequencing was performed on 3 different samples. Twelve pairs of primers were used to amplify overlapping fragments covering the 18S-ITS-1 gene sequences (Table 1). Confirmation of the $5^{\prime}$ end of the $18 \mathrm{~S}$ gene was performed by cloning the PCR product, amplified by the primers Suni (CAA CCTGGT TGA TCC TGC CC, Besnard-Cochennec 2001) and Boas (Cochennec et al. 2000), into the TA cloning vector (Invitrogen). Sequence determination of the cloned fragments was performed using the plasmid primers Topo F (GAC CAT GAT TAC GCC AAG C) and Topo R (CCC AGT CAC GAC GTT G) and the Big Dye V3 sequencing kit (Applied Biosystem).

Bonamia sequences were aligned using the CLUSTAL W algorithm (Thompson et al. 1994, Biomanager, Australian National Genomic Information Service).

Nucleotide sequences from Bonamia ostreae and B. exitiosa (Accession Number AF262995 and AF337563, respectively) were obtained from the GenBank database. The $B$. exitiosa ITS-1 sequence was obtained from Besnard-Cochennec (2001), and the Chilean Bonamia sp. ITS-1 sequence (Accession Number AY539840) was obtained from the GenBank database. 
consensus

Bonamia_ex

Bonamia-sp

Bonamia-os

consensus

Bonamia_ex

Bonamia-sp

Bonamia_os

consensus

Bonamia_ex

Bonamia_sp

Bonamia_os

consensus

Bonamia ex

Bonamia-sp

Bonamia-os

consensus

Bonamia_ex

Bonamia_sp

Bonamia_os

consensus

Bonamia_ex

Bonamia_sp

Bonamia_os

consensus

Bonamia_ex

Bonamia_sp

Bonamia_os

consensus

Bonamia_ex

Bonamia-sp

Bonamia_sp

consensus

Bonamia_ex

Bonamia_sp

Bonamia_os

consensus

Bonamia_ex

Bonamia_sp

Bonamia_os

consensus

Bonamia ex

Bonamia-sp

Bonamia_os

consensus

Bonamia_ex

Bonamia-os

consensus

Bonamia_ex

Bonamia_sp

Bonamia-os

consensus

Bonamia ex

Bonamia-sp

Bonamia_os

consensus

Bonamia ex

Bonamia-sp

Bonamia_os

consensus

Bonamia_ex

Bonamia-sp

Bonamia_os

consensus

Bonamia_ex

Bonamia_sp

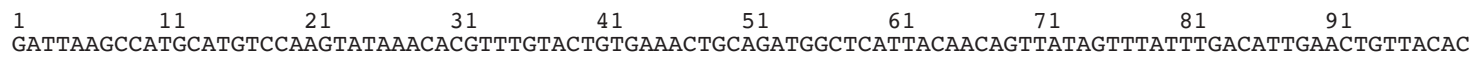
. 101 GGATAACCGTAGTAACCTAGGGCTAATACGTGACAAACCCTGC-TCG-CGGGAGTGCATATTAGCTGAAAACCAACTTTGGTTGAATAATAATATTTGTC

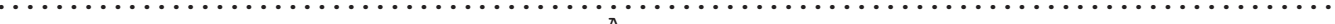

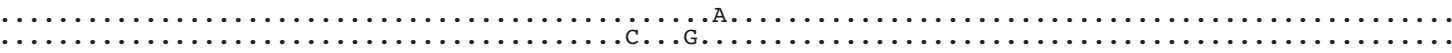
$\begin{array}{llllllllll}201 & 211 & 221 & 231 & 241 & 251 & 261 & 271 & 281 & 291\end{array}$ GGATCGCGTTGGCCTCGCCAGCGACATGTCATTCAAGTTTCTGACCTATCAGCTTGACGGTAGGGTATTGGCCTACCGTGGCTTTGACGGGTAACGGGGA

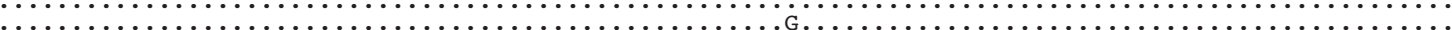
…

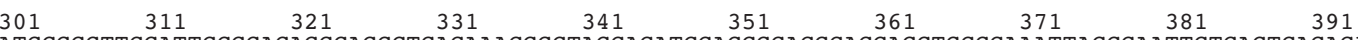
ATGCGGGTTCGATTCCGGAGAGGCAGCCTGAGAAACGGCTACCACATCCACGGGAGGCAGCAGGTGCGCAAATTACCCAATTCTGACTCAGAGAGGTAGT

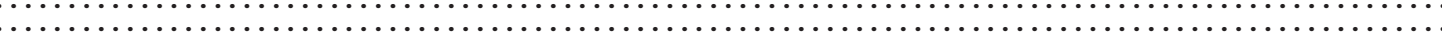
$\begin{array}{lllllllll}411 & 421 & 431 & 441 & 451 & 461 & 471 & 481\end{array}$

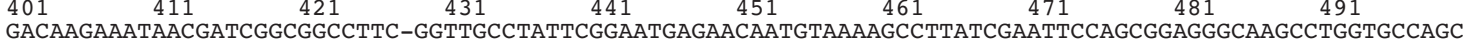

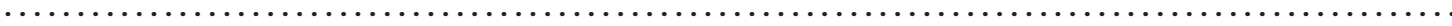

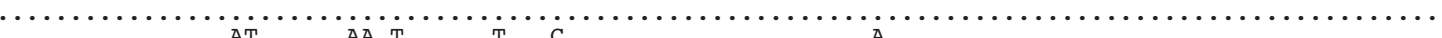

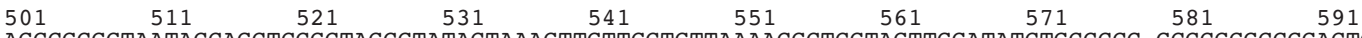
AGCCGCGGTAATACCAGCTCCGCTAGCGTATACTAAAGTTGTTGCTGTTAAAACGCTCGTAGTTGGATATCTGCCCCC-GCCCGGGCCGGACTCGC CG

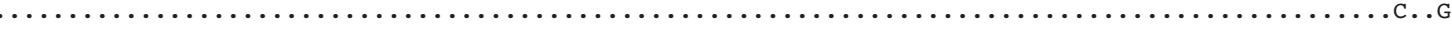
…
601
611
621
631
641
651
661
671
681
691

C ---GACGCACCTGCGCCTGCGGCCGGCCGCCGGGGCATAATTCAGGAACGCCGGTCTGGCCATTTAATTGGTCGGGCCGCTGGTCCTGATCCTTTAC

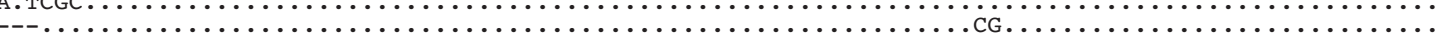

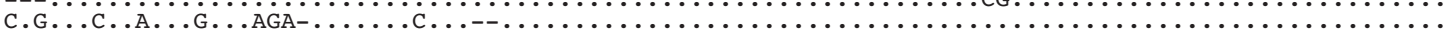

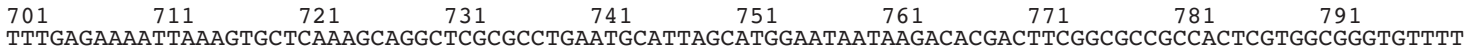

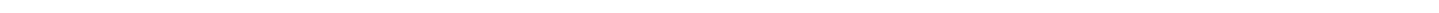

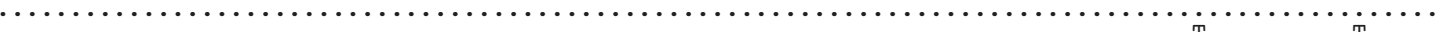

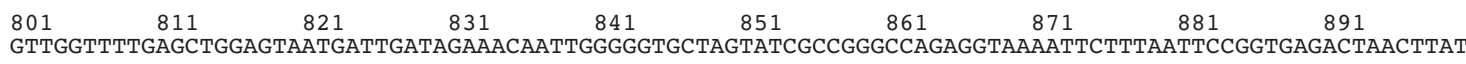
…

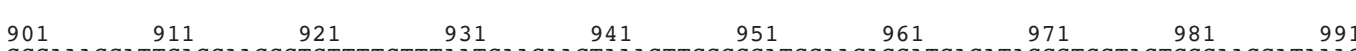
GCGAAAGCATTCACCAAGCGTGTTTTCTTTAATCAAGAACTAAAGTTGGGGGATCGAAGACGATCAGATACCGTCGTAGTCCCAACCATAAACGATGTCG

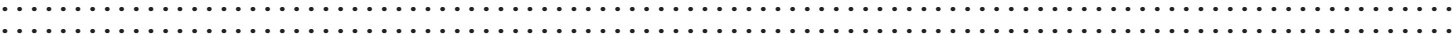

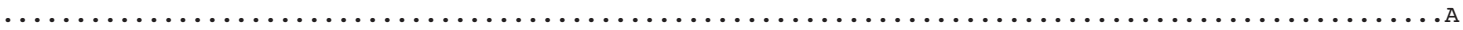
$\begin{array}{lllllllll}1001 & 1011 & 1021 & 1031 & 1041 & 1051 & 1061 & 1071 & 1081\end{array}$ ACTAAGCATTGGGCTACCAAACTTCCTCAGCACTTTATGAGAAATCAAAGTTTTCGGACTCAGGGGGAAGTATGCTCGCAAGAGTGAAACTTAAAGGAAT

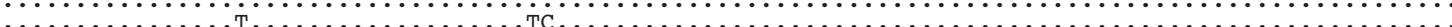

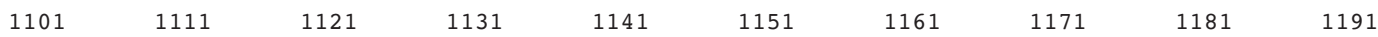
TGACGGAAGGGCACCACAAGATGTGGAGCCTGCGGCTTAATTTGATTCAACACGGGAAAACTTACCAGGTCCAGACATAGTAAGGATTGACAGATTAAAG

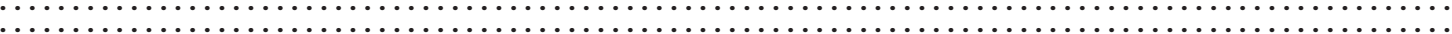
...

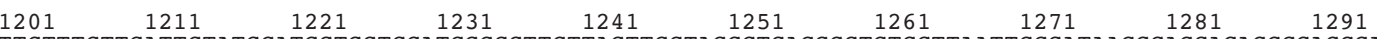
TTCTTTCTTGATTCTATGCATGGTGGTGCATGGCCGTTCTTAGTTCCTAGGGTGACCCCTCTGGTTAATTCCGATAACGGACGAGACCCCACCCATCTAA

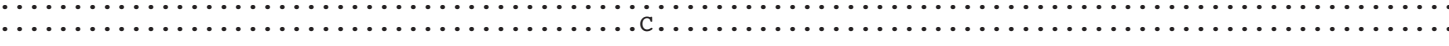

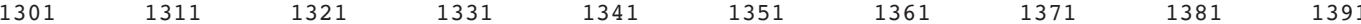
CTAGCCGGCGCTAACCCGGCGCCCAGCGCCCGTTAGCGGGGTGCAGCATTGCGCGCCCGGCTTCTTAGAGGGACTATCTGTGTCTCCAGCAGATGGAAGA

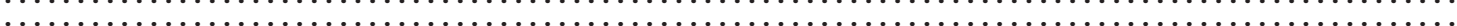

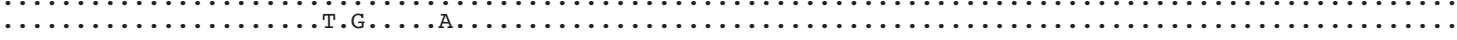
$\begin{array}{lllllllll}1401 & 1411 & 1421 & 1431 & 1441 & 1451 & 1461 & 1471 & 1481\end{array}$ TTGGGGCAATAACAGGTCAGGATGCCCTTAGATGCTCTGGGCTGCACGCGCGCTACAATGATGCGTTCAACGAGTTTGACCCGGCTTGACAAGGCCGGGT …

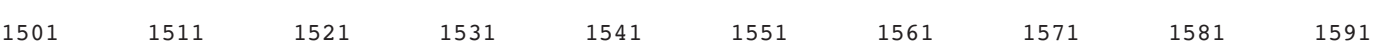
AATCTTCAACGCGCATCCAAGTGGGGATAGATGATTGCAATTGTTCATCTTGAACAAGGAATATCTAGTAAACGCAAGTCATCAACTTGCATTGATTACG

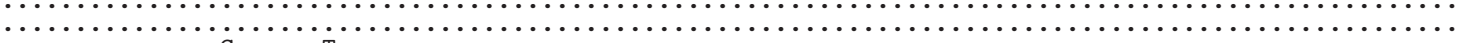
....... $1601 \quad 1611$ TCCСTGCCTTTG $\cdots \cdots \cdots \cdots$ $\ldots \ldots \ldots \ldots$

Fig. 1. Bonamia spp. Alignment of 18S rRNA partial gene sequences from Australia (Bonamia sp., Bonamia_sp), New Zealand (B. exitiosa, Bonamia_ex) and France (B. ostreae, Bonamia_os). Nucleotide mismatches are indicated below the consensus sequence; dashes represent nucleotide deletions with respect to consensus 


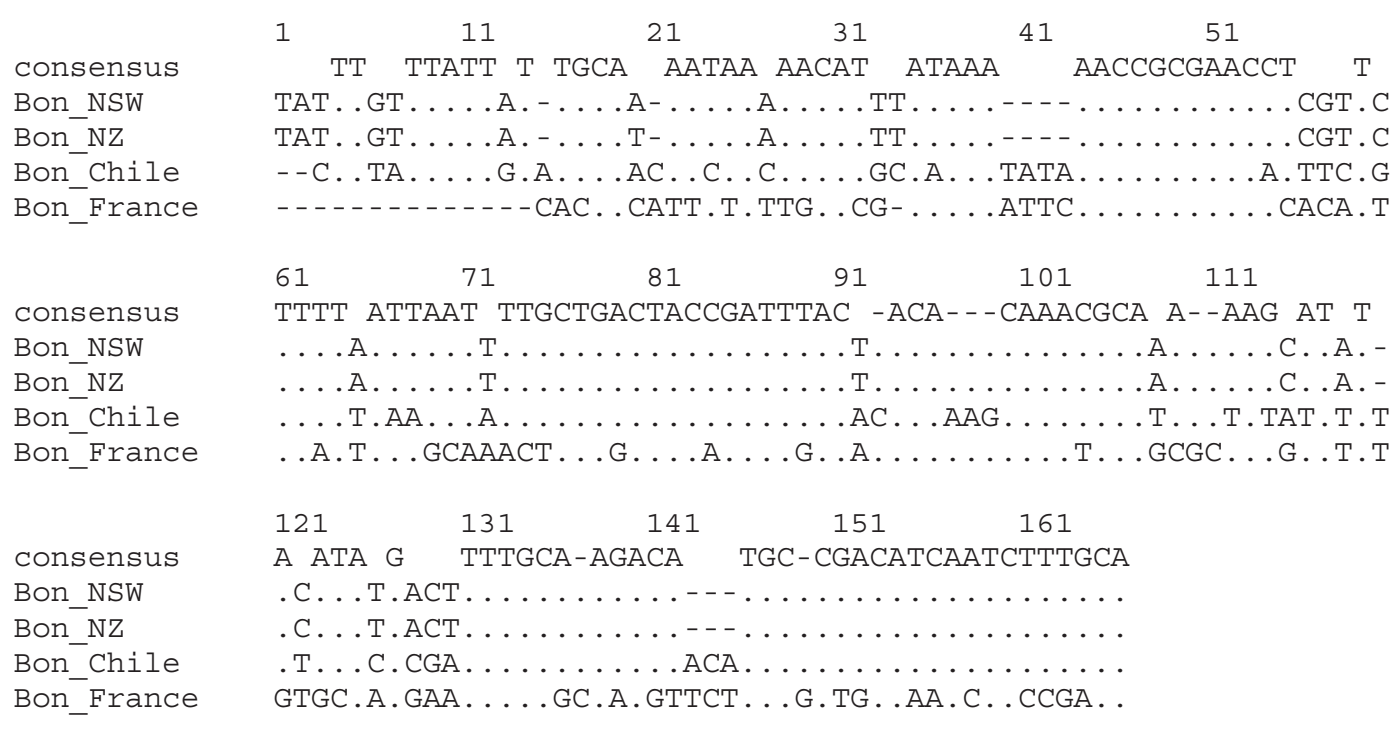

Fig. 2. Bonamia spp. Alignment of ITS-1 rRNA sequences from the Australian Bonamia sp.(Bon_NSW), the New Zealand B. exitiosa (Bon_NZ), the Chilean Bonamia sp. (Bon_Chile) and the French B. ostreae (Bon_France). Nucleotide identities are presented on the consensus lines; dashes represent nucleotide deletions

\section{RESULTS AND DISCUSSION}

The aim of this study was to explore the relationship, at a molecular level, of an Australian isolate of Bonamia sp. with previously described species of the genus, $B$. ostreae and $B$. exitiosa. In order to evaluate the relatedness of this Australian isolate to isolates from New Zealand and France, sequencing of the $18 \mathrm{~S}$ gene and ITS-1 region of the rRNA operon of Bonamia sp. was performed. The sequences obtained from the 3 NSW Bonamia isolates were identical. A nucleotide sequence comparison between the isolates from Australia, France and New Zealand was conducted. Results indicated that a higher level of nucleotide identity exists between the Bonamia sp. from Australia and B. exitiosa (New Zealand) than between Bonamia sp. and B. ostreae from France (Fig. 1). A 1598 base pair (bp) sequence of the $18 \mathrm{~S}$ gene of the Australian isolate presents 4 base pair mismatches and 11 base pair deletions when compared with the $B$. exitiosa sequence. On the other hand, differences between Bonamia sp. and $B$. ostreae sequences are more numerous, with 41 base pair mismatches, 5 base pair insertions and 10 base pair deletions.

Alignment of the ITS-1 rRNA sequences from Bonamia sp. and B. exitiosa presents further evidence of the genetic similarity between the Australian and New Zealand Bonamia. The isolates present only 1 base pair mismatch (Fig. 2). In addition, the ITS-1 sequence of a recently characterised Bonamia isolate from Chile (southern hemisphere) shows a higher level of similarity with the oceanic isolates than $B$. ostreae from France (northern hemisphere) (Fig. 2). It has been shown that the Chilean flat oyster Ostrea chilensis originates from New Zealand (Ó Foighil et al. 1999); it is therefore logical that their respective Bonamia isolates are closely related. Sequence analysis of the Australian isolate of Bonamia sp. demonstrates closer affinity with $B$. exitiosa compared to $B$. ostreae. In the light of this information, it is suggested that this Bonamia isolate from Australia be considered as a member of $B$. exitiosa. It has been hypothesised (Hine \& Jones 1994, Hine 1996) that, in this region, the parasite may have evolved in New Zealand and spread to Australia when commercial-size oysters were shipped live from New Zealand and laid in Victorian and Tasmanian waters prior to consumption (Dartnall 1969). With regards to surveillance of bonamiosis, the genetic similarity of the New Zealand and Australian isolates will allow the development of differential molecular diagnostic tests at various levels of specificity. A PCRrestriction fragment length polymorphism (PCR-RFLP) assay has been proposed to differentiate $B$. ostreae, $B$. exitiosa and $B$. roughleyi (Cochennec-Laureau et al. 2003). With ITS-1 sequences, it should be possible to design specific primers that would allow amplification of a given species in a single-step assay. However, more isolates need to be examined at the molecular level to provide further information on the diversity of Bonamia species before clear delineation of species and possible subspecies is justified. This is particularly true since recent reports of Bonamia sp. outside New 
Zealand and Australia have significantly broadened the recognised geographical distribution of this parasite (Campalans et al. 2000, Burreson et al. 2004, Kroeck \& Montes 2005). With regards to those recent isolates from Chile, the USA and Argentina, it is believed that the sequence data provided in this paper will help to clarify taxonomic relationships within the genus Bonamia and, more particularly, the species $B$. exitiosa. If $B$. exitiosa appears to be widely distributed within this geographical area, then, tools providing sound strain or subspecies identification will assist decision making concerning translocation of live molluscs. Together with robust epidemiological studies and biological evidence of biodiversity, the implementation of such tools could help avert the detrimental affects of translocation of live molluscs.

Acknowledgements. This study was partly funded by the Fisheries Research and Development Corporation (Project Number 2003/622) and the European Community Reference Laboratory for Molluscs Diseases. The authors thank S. Dworjanyn and I. Pirozzi (NSW Fisheries) for the collection of wild Ostrea angasi from estuaries in NSW and Jacqueline Campalans (Escuela de Ciencias del Mar, Universidad Catolica de Valparaiso, Chile) for the Chilean Bonamia isolate. We also thank T. Pye (CSIRO Livestock Industries, Australia) for the DNA sequencing.

\section{LITERATURE CITED}

Berthe FCJ, Hine PM (2003) Bonamia exitiosa Hine et al., 2001 is proposed instead of $B$. exitiosus as the valid name of Bonamia sp. infecting flat oysters Ostrea chilensis in New Zealand. Dis Aquat Org 57:181

Berthe FCJ, Burreson EM, Hine M (1999) Use of molecular tools for mollusc disease diagnosis. Bull Eur Assoc Fish Pathol 19:277-278

Besnard-Cochennec N (2001) Bonamia ostreae, parasite de l'huître plate, Ostrea edulis: sa position taxonomique parmis les parasites du groupe 'microcell', analyses des interactions hote/parasite chez plusieurs populations d'huitres plates. These de doctorat, Université de La Rochelle

Burreson EM, Stokes NA, Carnegie RB, Bishop MJ (2004) Bonamia sp. (Haplosporidia) found in nonnative oysters Crassostrea ariakensis in Bogue Sound, North Carolina. J Aquat Anim Health 16:1-9

Campalans M, Rojas P, Gonzalez M (2000) Haemocytic parasitosis in the farmed oyster Tiostrea chilensis. Bull Eur Assoc Fish Pathol 20:31-33

Editorial responsibility: Albert K. Sparks, Seattle, Washington, USA
Carnegie RB, Cochennec-Laureau N (2004) Microcell parasites of oysters: recent insights and future trends. Aquat Living Resour 17:519-528

Carnegie RB, Barber BJ, Culloty SC, Figueras AJ, Distel DL (2000) Development of a PCR assay for the detection of the oyster pathogen Bonamia ostreae and support for its inclusion in the Haplosporidia. Dis Aquat Org 42:199-206

Cigarría J, Elston R (1997) Independent introduction of Bonamia ostreae, a parasite of Ostrea edulis, to Spain. Dis Aquat Org 29:157-158

Cochennec N, Le Roux F, Berthe FCJ, Gerard A (2000) Detection of Bonamia ostreae based on small subunit ribosomal probe. J Invertebr Pathol 76:26-32

Cochennec-Laureau N, Reece KS, Berthe FCJ, Hine PM (2003) Mikrocytos roughleyi taxonomic affiliation leads to the genus Bonamia (Haplosporidia). Dis Aquat Org 54: 209-217

Dartnall AJ (1969) New Zealand seastars in Tasmania. Pap Proc R Soc Tasman 103:53-55

Grizel H (1997) Les maladies des mollusques bivalves: risques et prévention. Rev Sci Tech Off Int Epizooties 16:161-171

Heasman M, Diggles BK, Hurwood D, Mather P, Pirozzi I, Dworjanyn S (2004) Paving the way for continued rapid development of the flat oyster (Ostrea angasi) farming industry in New South Wales. Final Report to the Department of Transport \& Regional Services Project No. NT002/0195 June 2004 NSW Fisheries Final Report Series No. 66. NSW Fisheries, Nelson Bay

Hine PM (1996) Southern hemisphere mollusc diseases and an overview of associated risk assessment problems. Rev Sci Tech Off Int Epizooties 15:563-577

Hine PM, Jones JB (1994) Bonamia and other aquatic parasites of importance to New Zealand. NZ J Zool 21:49-56

Hine PM, Cochennec-Laureau N, Berthe FCJ (2001) Bonamia exitiosus n. sp. (Haplosporidia) infecting flat oysters Ostrea chilensis (Philippi) in New Zealand. Dis Aquat Org 47:63-72

Kroeck MA, Montes J (2005) Occurrence of the haemocyte parasite Bonamia sp. in flat oysters Ostrea puelchana farmed in San Antonio Bay (Argentina). Dis Aquat Org 63: 231-235

Ó Foighil D, Marshall BA, Hilbish TJ, Pino MA (1999) TransPacific range extention by rafting is inferred for the flat oyster Ostrea chilensis. Biol Bull (Woods Hole) 196: $122-126$

OIE (Office International des Epizooties) (2003) Bonamiosis. Manual of diagnostic tests for aquatic animals 2003, 4th edn. OIE, Paris. Also available at: www.oie.int/eng/ normes/fmanual/A_00037.htm

Thompson JD, Higgins DG, Gibson TJ (1994) CLUSTAL W: improving the sensitivity of progressive multiple sequence alignment through sequence weighting, position-specific gap penalties and weight matrix choice. Nucleic Acids Res 22:4673-4680

Submitted: December 17, 2005; Accepted: February 20, 2006 Proofs received from author(s): June 16, 2006 